\title{
The role of social pedagogues in the school environment - a topic for professional and social discussion ${ }^{1}$
}

\author{
Tomáš Čech
}

Palacky University in Olomouc, Faculty of Education, Institute of Education and Social Studies

When designing the monothematic issue of Pedagogická orientace entitled Child in Network of Risks we encountered a recurring social need for systematic prevention and management of risk behaviour in children and adolescents. This is mentioned, for example, in a paper by M. Procházka (2020) who analyses the cooperation between the school prevention methodologist and the teacher. In the Czech system of education, the establishment of the position of a school prevention methodologist (Decree No. 72/2005 Coll. on the provision of counselling services in schools and educational counselling centres) has been a clear benefit. However, we could speculate that the development of society calls for a more conceptual and systematic approach to addressing risk behaviour in schools and that the position of a school prevention methodologist, which is performed by a teacher with an accredited course and a slight relief in teaching duties, is no longer sufficient.

Reflections on who could take this role in Czech schools and provide the necessary support to teachers and learners in the development of competences concerning risk behaviour management have been considered for many years. The social pedagogue. A professional who is trained in supporting the process of socialization of children and youth as well as prevention and intervention in the event of risk behaviour. Specific experience with the establishment of this position in Slovakia is summarized in the following discussion paper by M. Niklová (2020). The social pedagogue position is also established in schools in other countries, for example in Germany or Russia. However, in the Czech Republic, only few educational counselling centres have the social pedagogue position. This is due to an insufficient legislative definition of the profession and its role in the school environment.

\footnotetext{
Author's note: Regarding the fact that this is a discussion paper concerning the role of social pedagogues in schools, we will appreciate any suggestions and experiences, not only from Czech schools but also from abroad. Please send any suggestions and reactions to tomas. cech@upol.cz.
} 
The first thoughts about establishing the social pedagogue profession in Czech education (cf. Soják \& Čech, 2010) appeared at least twenty years ago. The authors Lorencová and Poláčková (2001) based their reflections on the status of the school as a social institution which should develop pupils' life competences, specifically the ability to live with people from different classes and cultures, understand life in other countries, lead a healthy lifestyle as well as develop the precondition for becoming a good citizen and for lifelong learning.

The authors also looked at specific considerations on the role of the social pedagogue in schools, which they see in offering prevention and integrating social services. We do not agree with the opinion of both authors that social pedagogues should stand outside the school hierarchy. On the contrary, we believe that the position of the social pedagogue should be integrated in the school system and should have a clearly defined professional job content. The job content should be based on a general framework, including the standard tasks expected in the school environment, but in terms of function it should be based on the needs of the specific location and educational institution. However, we agree with the statement that the social pedagogue could be a link between the school, parents and other institutions including the Department of family and child care and the Department of social prevention and social-legal protection.

The role of the social pedagogue is outlined by the authors Lorenzová and Poláčková (2001) as follows:

- “Pupil's assistant and advocate (concerning the pupil's rights and dignity);

- Mediator in conflicts with pupils and parents;

- Coordinator with public administration;

- Initiator of cooperation with local educational institutions;

- Organizer of leisure activities and projects."

The authors suggest that "the social and educational approaches are based on a multidisciplinary concept, emphasise the educational aspects and focus primarily on the prevention of social deviations of children and youth, focusing on leisure activities, social education and social counselling in school, this in the sense of supporting self-help and the role of the counsellor as an educational facilitator". 
The role of the social pedagogue was also considered in the work of B. Kraus. In the first place, the author thought about the importance of school for an adolescent in parallel with the possible role of the social pedagogue in most school functions including socialization, education, care, counselling, recreation, professionalization and selective (cf. Kraus, 2008). The author also considered the context of the school environment including the material and spatial aspects but primarily the social-psychological climate of the school, which he, with reference to Lašek (2007), defines as "a more permanent social and emotional tuning of all participants who create it and experience it in interaction. This is a specific manifestation of the life of the school, reflecting the level of the whole environment including all of its participants." B. Kraus distinguishes the following areas of the work of the social pedagogue in the socio-psychological climate: relationships and processes inside the institution, pupil-teacher relationships, relationships between pupils, classroom climate, relationships between teachers, level and style of management of the whole institution, etc. From the perspective of the external environment, where the school plays an important role in the context of its location, the author emphasises the need for supporting the position of the school and cooperation with other local institutions (Kraus, 2008).

Similar conclusions were presented by Čerstvá and Čech (2009) who based their ideas on a qualitative research study conducted among elementary school directors. In view of the previous reflections of Kraus, directors perceive the climate of the school as a social institution as the key factor in terms of the school functioning. They claim that both internal and external functioning of the school as an educational and socializing institution is dependent on its relationships and climate which needs to be positively supported while providing the desired conditions and eliminating any negative effects. At the same time, the school must not work in isolation but must be perceived as an open institution and as part of the cultural and social life in the area. Other problems as reported by directors included a lack of professionals to address specific issues, difficult cooperation with external departments, excessive pressure on teachers and their competences (early risk of burnout) as well as the role of the school in extra-curricular education. In defining the social pedagogue and his/her competences, elementary school directors agreed that they would welcome this type of employee in order to ensure a comprehensive approach to addressing many of the previously mentioned social and educational issues. They believe that the problem 
with hiring of this professional lies in insufficient legislative definition of the social pedagogue, lack of funding for the establishment of this position and a clear definition of school competences (Čerstvá \& Čech, 2009).

The authors further specify the professional responsibilities of the social pedagogue in schools including the existing professional positions (school prevention methodologist, educational counsellor, school psychologist, special needs teacher). The aim should therefore be to "make the school environment healthier" and introduce a conceptual approach to resolving educational and social issues in schools (Čech, 2007).

Similar conclusions were also formulated by Procházka (2012). An analysis of increased risk behaviour and the implementation of primary prevention resulted in the need for the coordination of educational and preventive measures in schools. The preparation, implementation and evaluation of the school's prevention programme by one of the specialized teachers is limited by the real possibilities for their communication with all teachers as well as the chances for initiation of school-wide cooperation. The relatively independent position of the social pedagogue could help resolve the situation.

An important step towards the establishment of the social pedagogue position in the school environment is the project Social pedagogue in practice (Soják \& Čech, 2010) conducted at the Faculty of Education, Masaryk University. The aim of the project was to identify the benefits of the social pedagogue position in elementary schools. The project funded several positions in elementary schools for which students and graduates of Social education were selected by means of competition. These social pedagogues analysed the conditions and graduate opportunities in schools by means of several methods - reflective diaries, self-assessment questionnaires measuring the development of students' core competences as part of their practice and focus groups with trainee students and partner experts. The research identified the opportunities for social pedagogues in elementary schools.

The inclusion of social pedagogues in schools was also addressed by Mikulková (2007) who considered the problem from the perspective of a social pedagogue in practice. According to the author, social pedagogues would be useful in schools in many respects but again the problem is the absence of the social pedagogue position in the catalogue of professions, thus limiting the opportunities of social pedagogues, especially in education. 
The author defined social education as education of socialization the objective of which is "a good life". This concept makes it easier to understand the differences between social education and other disciplines, including its unique position in the system of educational and helping professions.

In terms of the absence of social pedagogues in schools, the author considers a similar problem-the work of a methodologist of preventive activities in educational and psychological counselling centres. According to the author (2007), this position is fully based on the competences of social pedagogues and their theoretical knowledge, but since this is not an existing position in terms of legislation, the social pedagogue position cannot be established in counselling centres. So even here, the position is still lacking. The practical skills and theoretical knowledge of a social pedagogue were used by Mikulková (2007) in her private social and educational counselling practice.

In this sense, she focuses on the following:

- preventive and intervention programmes in schools;

- social-educational programmes;

- field educational counselling;

- social activation services for families with children;

- lecturing, consultations and methodological activities;

- counselling services;

- individual counselling, etc.

The author shows the directions in which social education competences can be developed in the context of schools. The implementation of the principles of joint education has provided a new space for the opportunities of social pedagogues in schools. The authors Čech and Hormandlová (2020) outline the possible ways of cooperation between social pedagogues and other professionals in school counselling centres, including special needs teachers and school psychologists. Good practices concerning the employment of a social pedagogue in a school counselling centre were presented by Tomková et al. (2020). These inspirational examples of good practice have confirmed that social pedagogues can be useful in working with groups of learners, both in diagnosing the classroom climate as well as in the preparation and implementation of preventive or intervention programmes. The interviews 
with teachers also suggest the opportunity for supporting pupils from a socially disadvantaged or culturally different background. In addressing these issues, the social pedagogue becomes an intermediary between the school and the family or other institutions providing support to disadvantaged pupils or their families.

The efforts to establish the social pedagogue profession in the Czech society and specifically in schools have, in the long run, been supported by the Association of Educators in Social Pedagogy which brings together professionals and institutions involved in the training of social pedagogues. In 2020, the association issued the document Job content of a social pedagogue in elementary school (Náplň..., 2020) which defines the position and responsibilities of the social pedagogue in the school environment at multiple levels. The job content defines the work of a social pedagogue:

- in relation to the school management (responsibility for the work performed);

- in relation to teachers and other educational staff (development of the school climate and classroom climate, counselling for teachers);

- in relation to pupils (individual work with pupils, group work with pupils, crisis intervention);

- in relation to parents (interviews with parents, field work, educational boards);

- in relation to other actors (communication with the authority for social and legal protection of children, police of the Czech republic, communication with counselling and diagnostic institutions (in the Czech system these include educational and psychological counselling centres and educational care centres), communication with field social workers as well as low-threshold establishments for children and youth, etc.);

- in relation to the members of the school counselling centre (school prevention methodologist, educational counsellor, school psychologist, special needs teacher);

- in relation to the community (cooperation with the community, development of the community, promotion of social cohesion). 
The detailed proposals of the association gave rise to an innovation of undergraduate study programmes aimed at future social pedagogues in order for them to gain the required competences. It can therefore be concluded that social pedagogues are provided with the necessary competences for work in school counselling centres and may become their fully-fledged members. In this way, they can contribute to the achievement of the principles of joint education and the implementation of the strategies of the Czech Education Policy 2030+ (MEYS, 2020). We can only hope that the many years of efforts will be reflected in the forthcoming amendment to the Act on Educational Staff and that social pedagogues will find a stable and strong position of professionals capable of providing systematic support to all the actors in the process of education.

\section{References}

Asociace vzdělavatelů v sociální pedagogice. Retrived from: http://asocped.cz/.

Čech, T. (2007). Vision of the role of social pedagogue in making school healthier. In E. Řehulka et al., School and Health 2 (pp. 499-507). Brno: Paido.

Čech, T., \& Hormandlová, T. (2020). Profesní obraz školního speciálního pedagoga v podmínkách základní školy. Olomouc: Palacký University Olomouc.

Čerstvá, L., \& Čech, T. (2009). Sociální pedagog a vize jeho uplatnění v základní škole. In P. Soják (Ed.), Symposium sociální pedagogiky na PdF MU 2 (pp. 65-73). Brno: Masaryk Univerzity.

Kraus, B. (2008). Základy sociální pedagogiky. Praha: Portál.

Lašek, J. (2007). Sociálně psychologické klima školních tříd a školy. Hradec Králové: Gaudeamus.

Lorencová, J., \& Poláčková, V. (2001). Specifika pomáhání v podmínkách školy. In B. Kraus \& V. Poláčková et al., Člověk - prostředí - výchova. K otázkám sociální pedagogiky (pp. 190-197). Brno: Paido.

Mikulková, M. (2007). Sociální pedagogika a její místo ve školství . In Sociální pedagogika v teorii a praxi. Brno: Institut mezioborových studií.

MŠMT (2020). Strategie vzdělávací politiky ČR do roku 2030+. Praha: MŠMT. Retrieved from https://www.msmt.cz/vzdelavani/skolstvi-v-cr/strategie-2030

Náplň práce sociálního pedagoga v základní škole (2020). Asociace vzdělavatelů v sociální pedagogice. Retrived from: http://asocped.cz.

Niklová, M. (2020). Prevention of online risk behaviour in schools with regard to the socioeducational activity of the school social pedagogue. Pedagogická orientace, 30(4).

Procházka, M. (2020). Barriers to the implementation of primary prevention of risky behaviour in school in the context of teacher/ school prevention methodologist activities. Pedagogická orientace, $30(4)$.

Procházka, M. (2012). Sociální pedagogika. Praha: Grada.

Soják, P., \& Čech, T. (2010). Cesta do školy aneb výzkum potřebnosti a uplatnitelnosti sociálního pedagoga ve škole. In J. Němec et al., Výzkum zaměřený na... Základnísměry výzkumu katedry sociální pedagogiky PdF MU (pp. 109-119). Brno: Masaryk University. 
Tomková, A., Hejlová, H., Procházka, M., \& Najmonová, M. (2020). Spolupráce učitele s dalšími odborníky v realitě společného vzdělávání. České Budějovice: Pedagogická fakulta Jihočeské univerzity v Českých Budějovicích.

Vyhláška č. 72/2005 Sb., o poskytování poradenských služeb ve školách a školských poradenských zařízeních.

\section{Author}

doc. PhDr. Tomáš Čech, Ph.D., Palacky University in Olomouc, Faculty of Education, Institute of Education and Social Studies, Žižkovo nám. 5, 77140 Olomouc, e-mail: tomas.cech@upol.cz 